\title{
Regional socio-economic impacts of intensive forest management, a CGE approach
}

\section{Karttunen, Kalle}

2018-11

Karttunen , K, Ahtikoski , A , Kujala , S , Törmä , H , Kinnunen , J , Salminen , H , Huuskonen, S , Kojola , S , Lehtonen, M , Hynynen, J \& Ranta , T 2018 , ' Regional socio-economic impacts of intensive forest management, a CGE approach ', Biomass \& Bioenergy , vol. 118 , pp. 8-15 . https://doi.org/10.1016/j.biombioe.2018.07.024

http://hdl.handle.net/10138/298640

https://doi.org/10.1016/j.biombioe.2018.07.024

cc_by_nc_nd

publishedVersion

Downloaded from Helda, University of Helsinki institutional repository.

This is an electronic reprint of the original article.

This reprint may differ from the original in pagination and typographic detail.

Please cite the original version. 
Research paper

\title{
Regional socio-economic impacts of intensive forest management, a CGE approach
}

\author{
Kalle Karttunen $^{\mathrm{a}, *}$, Anssi Ahtikoski ${ }^{\mathrm{b}}$, Susanna Kujala ${ }^{\mathrm{c}}$, Hannu Törmäc, Jouko Kinnunen ${ }^{\mathrm{d}}$, \\ Hannu Salminen $^{\mathrm{b}}$, Saija Huuskonen ${ }^{\mathrm{b}}$, Soili Kojola ${ }^{\mathrm{b}}$, Mika Lehtonen ${ }^{\mathrm{b}}$, Jari Hynynen ${ }^{\mathrm{b}}$, Tapio Ranta $^{\mathrm{a}}$

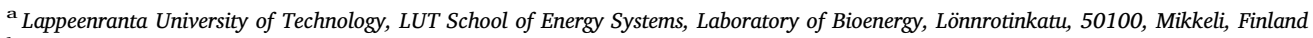 \\ ${ }^{\mathrm{b}}$ Natural Resources Institute Finland, PL 18, 01301, Vantaa, Finland \\ ${ }^{\mathrm{c}}$ University of Helsinki, Ruralia Institute, Kampusranta 9, 60320, Seinäjoki, Finland \\ d Statistics and Research Åland, P.O. Box 1187, AX-22111, Mariehamn Åland, Finland
}

\section{A R T I C L E I N F O}

\section{Keywords:}

CGE modelling

Demand

Wood

Simulation

GDP

Employment

\begin{abstract}
A B S T R A C T
The demand for and supply of forest biomass have both been increasing in recent years, which will set new requirements for forest management. Thus, new studies on regionally suitable forest management regimes to fulfill the needs of potential new investments and the impacts on wood supply potential on regional socioeconomic welfare are called for. The aim of this study was to examine the impacts of intensive forest management due to increased demand for wood biomass, from the regional economy point of view. In particular, the impact of intensive forest management on 1) regional gross domestic product (GDP), 2) private consumption, and 3) employment were assessed. The study was carried out by using computable general equilibrium (CGE) modelling combined with the requisite statistics and simulation of regional forest potential in the future. The results showed that total regional forest biomass supply with more intensive forest management could be increased annually on average by $26 \%\left(1.7 \mathrm{Mm}^{3}\right)$ by 2030 compared to the business as usual (BAU) scenario. In this study, regional demand was increased by a hypothetical saw mill $\left(0.5 \mathrm{Mm}^{3}\right)$ and biorefinery $\left(0.7 \mathrm{Mm}^{3}\right)$. Total regional socio-economic benefits could be $2.8 \%$ (€150 M) for GDP, 1.5\% (€49 M) for private consumption and $1.6 \%$ (780 person-years) for employment, larger by 2030 than in the BAU scenario including multiplier effects. The study demonstrated how much regional socio-economic welfare would increase if regional wood demand with new investments combined with more intensive forest management and wood supply had more attention paid to it.
\end{abstract}

\section{Introduction}

Forests in Finland have an important economic and ecological role, which implies that sustainable management of the forests is a desirable goal. Further, sustainable use of natural resources to mitigate climate change is one of the biggest challenges globally [1]. Tackling climate change requires the changes at both regional and global levels. Sustainable forest management also has a significant role in regional development as a part of other rural sectors [2]. The energy supply sector has been the biggest source of greenhouse gas (GHG) emissions (35\%, 2010) with the fastest growth (47\%) between 2000 and 2010 [3]. Recently, regional analyses have been used to find socio-economically renewable energy production, for instance in western Finland [4], in Brazilian ethanol production [5] and for the energy-efficiency of households in Spain [6]. Regional socio-economic analysis, however, requires not only the statistical information but also in-depth sectorwise knowledge of the area. In this study, we introduce a regional socioeconomic analysis by utilizing combined method of CGE modelling with forest management simulations.

Need for the industrial round wood and energy wood has been increasing due to recent investments in the forest industry and energy sectors [7]. In Finland, the volume of round wood harvested domestically was $58.5 \mathrm{Mm}^{3}$ in 2015 [7], whereas the aim is for this to increase to $80 \mathrm{Mm}^{3}$ by 2025 [8]. In addition, the Finnish national energy and climate strategy aims to use $13.5 \mathrm{Mm}^{3}$ (i.e., $27 \mathrm{TWh}$ ) forest-based chips in heat and power production by 2020 [9]. In $2015,8.0 \mathrm{Mm}^{3}$ of forest fuels were consumed in heat and power plants $\left(7.3 \mathrm{Mm}^{3}\right)$ and in small buildings $\left(0.7 \mathrm{Mm}^{3}\right)$ [10]. Small-diameter wood was the most used forest fuel $\left(3.9 \mathrm{Mm}^{3}\right)$. Forest fuel usage was growing rapidly from 2000 , but since 2010 the use has been declined. Energy wood can complement

\footnotetext{
* Corresponding author.

E-mail address: kalle.karttunen@lut.fi (K. Karttunen).
} 
industrial round wood procurement and forest management when the operations are linked together, but industrial round wood can be solely used for energy purposes if there are no other industrial uses. The development of the forest biomass value chain should be seen as integrating industrial and energy wood supply chains [11]. Wood procurement has been targeted at getting more and cheaper logging residues from final cuttings. However, the integrated harvesting of industrial round wood and energy wood from dense young stands has been shown to be a feasible stand management alternative [12]. Forest management simulations [12-14] have been used to analyse forest biomass potentials at stand level, and the results have shown the costeffectiveness of the use of wood from dense young stands for energy. The profitability of using the first thinning removal either for industrial round wood, energy wood or both is mainly dependent on the price difference between energy wood and pulpwood.

The availability of energy wood has been studied at the national level in Finland by using GIS-based methodology [15-18]. In addition, several energy wood potential studies have been carried out at the regional level [19-23]. In Finland, the potential of small-diameter energy wood has been estimated to vary between 6.2 and $10.4 \mathrm{Mm}^{3}$ depending on harvesting method, whereas the potential of logging residues $\left(4.0-6.6 \mathrm{Mm}^{3}\right)$ and stumps $\left(1.5-2.5 \mathrm{Mm}^{3}\right)$ has been estimated as being much lower depending on annual cutting levels [17]. However, based on the results of a range of studies, there is a large variation in energy wood availability in Finland especially for final cutting removals. For example, according to Nivala et al. [18], the technical energy-wood potential varied between 6.2 and $8.3 \mathrm{Mm}^{3}$ for small-diameter wood, 6.6-11.6 $\mathrm{Mm}^{3}$ for logging residues, and 7.1-12.0 $\mathrm{Mm}^{3}$ for stumps, when the maximum technical energy wood potential from final cuttings is based on the maximum sustainable level.

The differences between the studies on energy wood potential are usually dependent on the restrictions set for the different types of potential definitions. Energy wood estimates are usually presented for either theoretical potential [24], technical potential [16-18], or economic and ecological potential, all using different restrictions. Practical energy-wood potential can be estimated when utilizing forest owners' willingness to supply energy wood $[25,26]$. For example, a study of forest owner willingness to supply energy wood at the South Savo region showed that small-diameter energy wood $(76-81 \%$ of forest owners are willing to sell it) and logging residues (76\%) are favored by forest owners, whereas stumps are not (51\%) [26]. The ability to pay for energy wood and price elasticities based on supply and demand of energy wood could be applied in the availability analysis. Further, the energy wood use and price development are affected by many external factors, such as the price development of emission allowances and electricity [27].

For assessing the welfare impacts of intensive forest management on a regional economy, we applied computable general equilibrium (CGE) modelling. Contrast to traditional input-output (I-O) models [e.g. Ref. [28]], CGE modelling incorporates an endogenous demand and price system, substitutability in production and demand, optimization of agent behaviour, factor scarcity, and a distinctively more detailed treatment of institutions and the macroeconomic environment [29]. The principal data source for a CGE model is use and supply tables of the national accounting, coupled with additional data on employment, consumption, taxation and transfers. Technically, the CGE model is a system of linear and non-linear equations describing the utility maximizing behaviour of consumers, profit maximizing of the producers and equilibrium conditions and constraints imposed by the economic environment. Then, the equations are solved simultaneously within suitable programming tools such as the GEMPACK or GAMS software packages [29-31]. Having solved the model for the initial period to replicate a particular year (a benchmark) in the past, a dynamic baseline growth path (business-as-usual) of the economy needs to be simulated in the model in order to be able to compare other scenarios related to reduced timber supply due to pest infestation, for example
[32]. In brief, a CGE model is a mathematical presentation of the economy, from a household to a country, even to the entire world economy, enabling an assessment of welfare impacts associated with scenarios and/or policies [33,34].

Traditionally, CGE models have been used to study international trade, taxes and economic policy packages [35]. More recently, CGE models have been applied to study forest sector policies as well. For instance, Wiebelt [36] studied how macroeconomic policies affect forest resource use in Brazil, Alavalapati et al. [37] analysed distributional effects of an increase in the stumpage price in Canada; Gan [38] studied the potential impacts of forest certification on welfare and trade patterns; Das et al. [39] analysed the economic effects associated with environmental regulations and technical changes in the US forestry sector and Stenberg and Siriwardana [40] examined the economic effects of selective logging, stumpage prices and set-aside areas on the Philippine economy. Most recently, CGE models have been applied to assess climate change mitigation policies [for an exhaustive review, see Ref. [34]], forest-based carbon sequestration policy [41] and the economic impacts of pest infestation [32]. However, there are few (if any) CGE articles tackling the economic potential of intensive forest management. Our study is an attempt to fill this gap.

South Savo is one of the more important regions for forest biomass supply in Finland with a share of about $10 \%$ of total harvesting supply [7]. However, the local use of industrial pulpwood is low, because pulp mills are situated in neighbouring regions. Therefore, over half of the forest biomass is used outside the region. In 2016, the industrial round wood demand of South Savo was $2.7 \mathrm{Mm}^{3}$ and energy wood demand was $0.4 \mathrm{Mm}^{3}$, whereas the volume of harvested round wood was $6.9 \mathrm{Mm}^{3}$ and energy wood $0.5 \mathrm{Mm}^{3}$ [7]. The regional aim of South Savo is to increase total forest biomass supply to $8 \mathrm{Mm}^{3}$ and regional demand to $4 \mathrm{Mm}^{3}$ by 2020 . The regional target for energy-wood demand has been set to $1.0 \mathrm{Mm}^{3}$ by 2020 [42]. Regional wood demand investments have been discussed publicly by increasing the use of pine logs by a new sawmill and energy wood by a biorefinery (biocoal pellet factory). Further, the regional analysis of South Savo showed that the total technical potential varies between 1.9 and $2.8 \mathrm{Mm}^{3}$, of which smalldiameter wood fluctuates between 0.4 and $0.7 \mathrm{Mm}^{3}$, logging residues between 0.7 and $1.0 \mathrm{Mm}^{3}$ and stumps between 0.7 and $1.1 \mathrm{Mm}^{3}$ [18]. Correspondingly, Anttila et al. [17] have assessed the delimbed energy wood potential as being $0.5 \mathrm{Mm}^{3}$, whole trees $0.7 \mathrm{Mm}^{3}$, and integrated cutting of small-diameter wood $0.4 \mathrm{Mm}^{3}$, but the averages of logging residues $\left(0.6 \mathrm{Mm}^{3}\right)$ and stumps $\left(0.3 \mathrm{Mm}^{3}\right)$ were much lower than those estimated by Nivala et al. [18].

In the short term, wood supply potential could be increased by intensifying thinnings, conducting fertilizations mainly on mineral soils, executing ditch network maintenance (DNM) on peatlands and scheduling final cuttings according to recommendations, or even bringing forward the final cuttings. In addition, silviculture could also be modified to increase wood supply in the longer run. In this study, we constructed a forest management entity which aimed to producing the required amount of round wood for both the new sawmill and biorefinery planned for construction in the South Savo region in eastern Finland. In practice, this resulted in considerably more intensive forest management than there has been in recent years in the region. The South Savo region was selected as a case study because it represents one of the important forest biomass supply areas in Finland due to the existing forest structure [43] and wood export volumes [7]. The aim of the study was to examine the impacts of this intensive forest management (due to increased demand for round wood) from the regional economy point of view. The impacts on 1) regional GDP, 2) private consumption, and 3) employment were of primary interest. 


\section{Materials and methods}

\subsection{CGE model}

For assessing the socio-economic impacts of intensive forest management, we applied a computable general equilibrium (CGE) model called RegFinDyn [44]. The regional RegFinDyn model is a multisector and inter-regional bottom-up model in which the regional effects of a change in economic conditions are simultaneously solved for all regions [e.g. 44]. National macro results for economic growth, employment, income, consumption, tax revenues, public services and trade etc. Are calculated alongside the regional results. As a multisector model, it can be applied to many research topics [e.g. Refs. [4,44,45]]. The model has been influenced by the Australian TERM and MMRF models [e.g. Refs. [46-48]].

The regional RegFinDyn simulation model (developed by the University of Helsinki, Ruralia Institute) is based on established microand macroeconomic theories, well-tested applied mathematical solution algorithms and the official accounting figures of Statistics Finland for national and regional economies. For example, the behaviour of enterprises and households are derived from the first-order conditions of their profit and utility maximisation problems, respectively.

In addition to the time dimension, the dynamic model takes into account production and income, the effects of relative prices, non-linear decision making by the actors, and resource constraints, like the adequacy of capital and labour. It is assumed that "everything affects everything" in the economy. The model describes both markets for goods and services and markets for factors of production. Each sector produces goods and services by using two inputs: capital and labour. For the forest sector, the stumpage is disaggregated from the rest of the capital stock as an input of its own. The key assumption is that there is competition between inputs, intermediate and final goods and services. Domestic and foreign goods and services compete in the setting of supply and demand. Inputs, intermediates, goods and services are imperfect substitutes at their markets. The structure of the RegFinDyn model is described in following figure (Fig. 1).

In this application, the RegFinDyn model was calibrated to $42 \mathrm{sec}-$ tors (the forestry sector divided into nine different kinds of wood and the rest of the sector) and 19 regions (all the provinces of Finland) with baseline 2013 data [49,50]. Additional data for this case were gathered from various official statistics [e.g. Refs. [51,52]] and MOTTI stand simulator results. In dynamic quantifications, the CGE method requires a baseline (business as usual, BAU) that describes an estimated economic development without the change in economic conditions. The baseline was formed using official forecasts [e.g. Refs. [51,53-55]].

Apart from sectorial and input disaggregation, the model closure (i.e. the choice of endogenous and exogenous variables) was customized for this analysis. As the growth of the forest resources currently surpasses the demand for stumpage, the stumpage factor was made available at a constant price. Thus, its supply curve was assumed to be horizontal, instead of being upward-sloping. Furthermore, the CGE model was linked to the regional results of the MOTTI simulation model by taking in the MOTTI results as exogenous variables. Therefore, as the use of timber in South Savo was exogenized, the extra-regional demand for timber was made endogenous. In addition, the local input use (and the production levels) within the sectors assumed to invest in new production facilities was made exogenous, which in turn required that the external demand for these industries was made endogenous.

The model was run and solved with the General Equilibrium Modelling PACKage (GEMPACK) software [56] for a 17-year-long simulation period (2014-2030). The effects on regional GDP, employment and private consumption etc. have been measured as differences between the results from the scenario and baseline simulations. The simulation results of the RegFinDyn model include not only the direct and indirect impacts of the changes within the production system, but also the consequential impacts brought about as the impact wave proceeds into income, consumption, investments and interregional migration.

\subsection{Forests at the case area}

The study focused on the South Savo region in eastern Finland covered by the stand grid data shown in Fig. 2. Half of the forest area of South Savo region consists of younger stands (development classes A0, S0, T1, T2, 02 in Fig. 3) the other half comprising older stands (03, 04 in Fig. 3). There are 1179000 ha of wood production land in the South Savo region, of which the average growing stock volume on forest land is $144 \mathrm{~m}^{3} \mathrm{ha}^{-1}$ and the average annual growth is $7.4 \mathrm{~m}^{3} \mathrm{ha}^{-1}$ (NFI11) [7]. The current forest resources in the South Savo region were calculated from the NFI11 (field work 2009-2013) data, which consist of 4067 systematically located sample plots on forest land and on the land available for commercial wood production. These plots represented various site types according to the site fertility level between corresponding mineral soils (Mineral heath) and peatlands (Spruce and pine mires) (Table 1).

Stand projections were based on the Motti stand simulator. Motti is

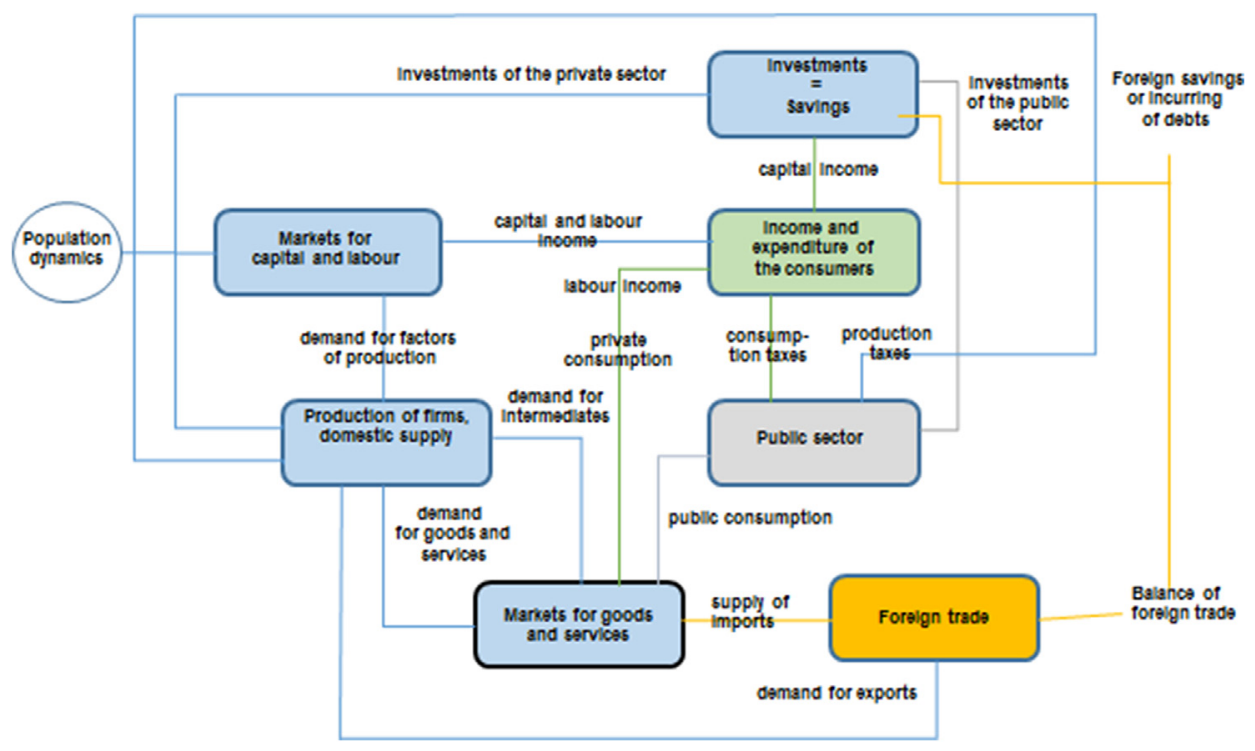

Fig. 1. The structure of the RegFinDyn model. 


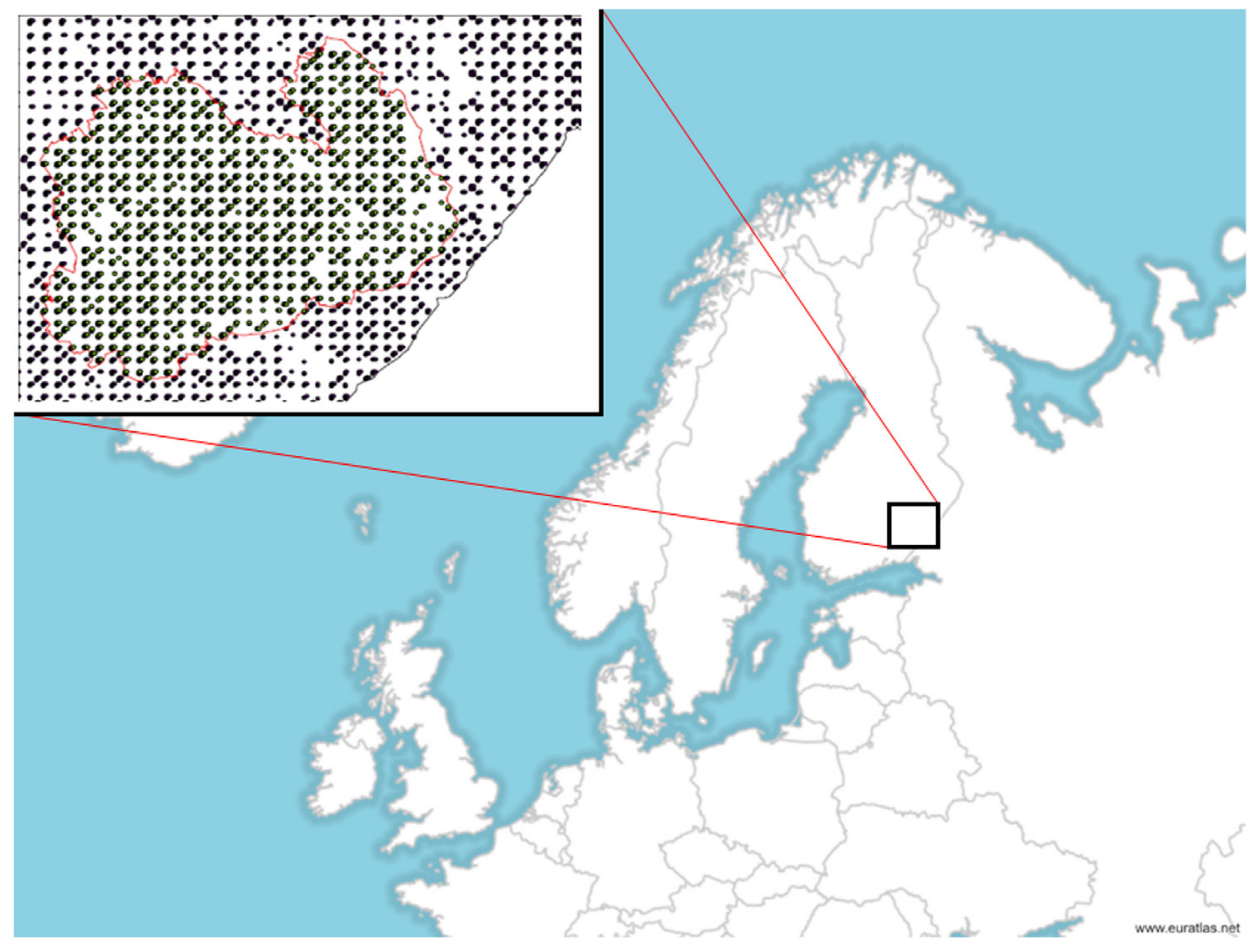

Fig. 2. The NFI stand data plots located in the South Savo region in eastern Finland.

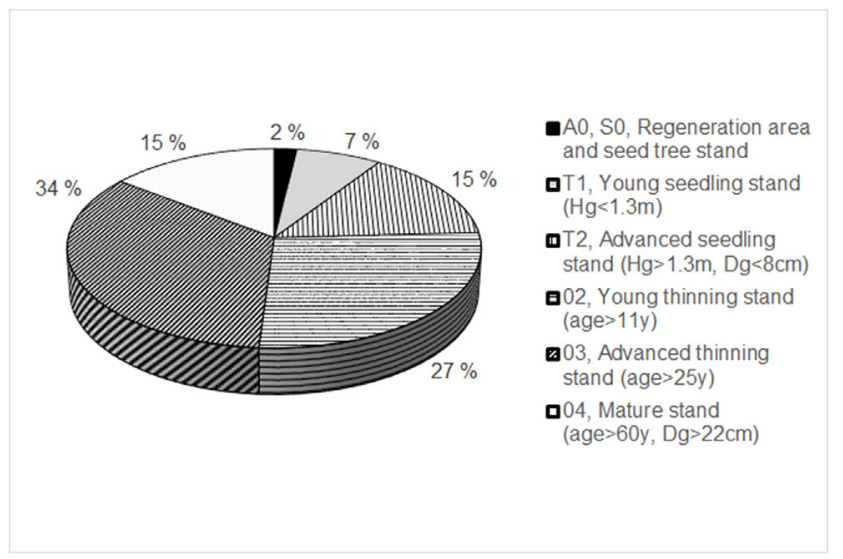

Fig. 3. The forest structure in the South Savo region by development classes (NFI11 [7]). The total area, 1179000 ha, comprises forest land on the land available for wood production. $\mathrm{Hg}=$ stand basal area weighted mean height $(\mathrm{m}), \mathrm{Dg}=$ stand basal area weighted mean diameter at breast height $(\mathrm{cm})$, $\mathrm{T}=$ stand age (years).

Table 1

Number of plots in NFI11 data set according to site fertility.

\begin{tabular}{llllll}
\hline & Site fertility & Mineral health & Spruce mire & Pine mire & Total \\
\hline 1 & Herb-rich & 1104 & 220 & 12 & 1336 \\
2 & Mesic & 1705 & 240 & 55 & 2000 \\
3 & Dryish & 455 & 18 & 179 & 652 \\
4 & Dry & 19 & 0 & 60 & 79 \\
Total & & 3283 & 478 & 306 & 4067 \\
\hline
\end{tabular}

a stand-level forest management and decision support tool that consists of stand-level models and distance-independent individual-tree models for predicting stand dynamics (regeneration, growth and mortality) and stand structure $[57,58]$. The growth and yield models of the Motti system are based on extensive empirical data covering all commercial wood tree species $[59,60]$. The predicted responses to different forest management practices are based on empirical data, which covers all common forest management practices applied in practical forestry in Finland over recent decades. The performance of the Motti simulator has been evaluated with respect to NFI data [59], as well as in permanent long-term experimental data [61-63]. Motti has been applied widely in analyses from stand-level to regional and national levels [e.g. $[59,64]]$. In this study, the timing of simulated commercial thinnings followed silvicultural recommendations and was defined by thinning guidelines [65], likewise the timing of final cuttings was defined by stand mean diameter. The time span of the simulated scenarios was 15 years, considered to be "short-term", and the results are given as an average level from three five year periods. The principles of stand management practices in management schedules were similar to the stand management principles described in detail by Hynynen et al. [59].

\subsection{Study scenarios}

The intensive forest management (INT) scenario was compared to the baseline management (Table 2). In the baseline management stand development was presented as a business as usual scenario (BAU), which described the status quo of both the prevailing silvicultural activities (including commercial cuttings, 2015) as well as current demand for round wood (2015). Thus, there were no new regional woodbased investments during the study time horizon, 2015-2030. The intensive forest management scenario included the assumption that demand for round wood will increase in the South Savo region due to the construction of two new plants: a sawmill and a biorefinery. Accordingly, forest management has to be adjusted for this, resulting in an annual increase of ca. $0.5 \mathrm{Mm}^{3}$ (sawmill) and $0.7 \mathrm{Mm}^{3}$ (biorefinery) in wood supply. The increased annual values were assumed to be realized from the year 2019 onwards until the end of the time horizon, 2030 both plants are designed to be fully functional in 2019 . 
Table 2

Intensive forest management regime with the increase in demand as well was compared to the business as usual scenario.

\begin{tabular}{|c|c|c|c|}
\hline Scenario & Acronym & Supply Description & Demand description \\
\hline Business as usual & BAU & Level of forest management practices remain at current level & No additional investment \\
\hline $\begin{array}{l}\text { Intensive forest management and regional increase in } \\
\text { demand }\end{array}$ & INT & $\begin{array}{l}\text { Intensive forest management with integrated harvesting of } \\
\text { first thinning }\end{array}$ & $\begin{array}{l}\text { Regional investment of saw mill and } \\
\text { biorefinery }\end{array}$ \\
\hline
\end{tabular}

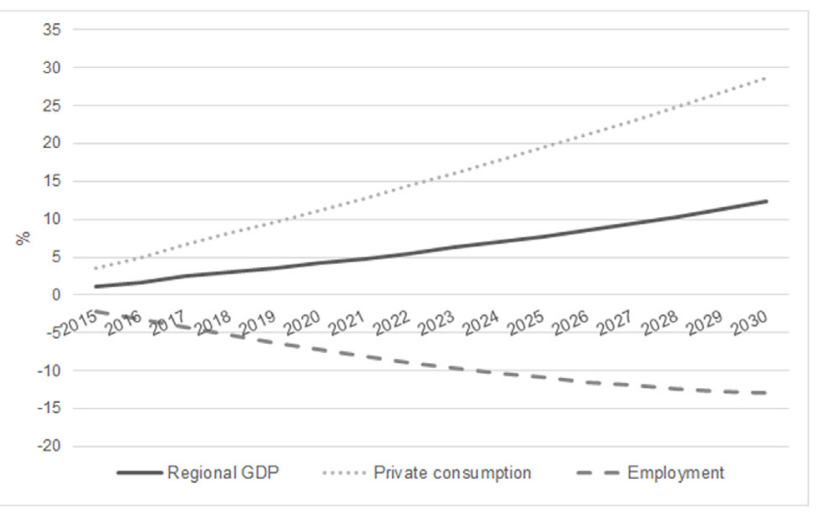

Fig. 4. Regional economic development of South Savo from 2015 to 2030 compared to year 2013 in BAU scenario.

\section{Results}

\subsection{Socio-economic impacts on regional welfare}

Business as usual scenario (BAU) corresponds to the expected development of the South Savo's regional economy, ceteris paribus. The BAU scenario was based on historical statistical data, as well as on official long-term macroeconomic and demographic forecasts. The development of regional GDP and private consumption are expected to increase by 2030 (Fig. 4). The increase in private consumption is stronger than the growth of regional GDP. Employment is expected to decrease in South Savo mainly because of the past development in employment. In addition, the unfavourable age structure of the work force in South Savo has an effect on the assessed decline.

The results of the intensive forest management scenario (INT) were compared to BAU scenario, showing positive outcomes in general (Table 3). The increased wood demand along with the investments and production of the sawmill (pine timber) and the biorefinery (biocoal pellets) would generate positive socio-economic impacts compared to the BAU scenario. According to the results, the realization of the INT scenario would have a clear positive effect on regional GDP, private consumption, employment, investment and population in South Savo by 2030 . The biggest percentage change would concern investments, $8.9 \%$. The sawmill and the biorefinery would require significant investments that would raise the total amount of investment in the region. The absolute impact on regional GDP would be about $€ 150$

Table 3

The cumulative change (absolute and percentage) of the regional GDP, private consumption, employment and population by 2030 in Intensive management (INT) scenario compared to baseline (BAU).

\begin{tabular}{lll}
\hline & INT & \\
\cline { 2 - 3 } & Absolute change & \% change \\
\hline Regional GDP (M€) & 150 & 2.8 \\
Private consumption (M€) & 49 & 1.5 \\
Employment (person-years) & 780 & 1.6 \\
Investments (M€) & 91 & 8.9 \\
Population (persons) & 525 & 0.4 \\
\hline
\end{tabular}

million by 2030 . The corresponding increase in employment would be 780 person-years. The impacts on employment do not concern only the sawmill, biorefinery and forestry sectors; sectors such as construction, manufacture of machinery and equipment and mining and quarrying would also gain from the scenario. Improved employment is one of the reasons why population of South Savo would increase as well.

The sensitivity analysis showed that the assumptions made on the functioning of the labour market do not have a significant impact on the results, but the assumption about the new production levels does. In the calculations, it is presumed that the wage level will stay unchanged in the policy scenario (compared with the corresponding years in the baseline scenario). When the wage level reacts to changes in labour demand, the impact on regional GDP changed only by about $€ 0.01$ million compared to the original results. When the assumptions of the production level of the sawmill and the biorefinery are changed, the results vary considerably more. For instance, a 50\% decrease in the assumed production level of the sawmill and the biorefinery would mean a smaller impact on regional GDP of $€ 22$ million and over 200 person-years less employment effect compared to the results presented above.

\subsection{Forest biomass according to scenarios}

Forest biomass supply potential was $6.58 \mathrm{Mm}^{3}$ for the BAU scenario and $8.32 \mathrm{Mm}^{3}$ for the INT scenario by 2030 (difference $1.74 \mathrm{Mm}^{3}$ ) (Table 4). The increase from 2015 was $0.24 \mathrm{Mm}^{3}$ (BAU) and $1.51 \mathrm{Mm}^{3}$ (INT). The more intensive forest management generated about $20 \%$ more forest biomass during 15 year time period to $2030\left(1.27 \mathrm{Mm}^{3}\right)$ compared with BAU scenario. The 5-year average of cumulative percentage shows the more stable development for BAU scenario than INT scenario (Table 4). It can be seen that the cumulative percentage of energy wood was higher than round wood in both scenarios. The total increase between round wood and energy wood between 2015 and 2030 was $0.09 \mathrm{Mm}^{3}$ (round wood) and $0.15 \mathrm{Mm}^{3}$ (energy wood) for the BAU scenario, whereas for the INT scenario, the figures were $0.82 \mathrm{Mm}^{3}$ and $0.69 \mathrm{Mm}^{3}$, respectively. The average of cumulative percentage change is higher for energy wood than round wood in both scenarios (Table 5).

More intensive forest management scenario (INT) decreased the growing stock volume (average $109 \mathrm{~m}^{3}$ ) on wood production land compared with the BAU scenario, in which the amount of growing stock remained almost at the same level from the beginning to the end of period, on average $156 \mathrm{~m}^{3} \mathrm{ha}^{-1}$, which was $7 \%$ points higher than the current level $144 \mathrm{~m}^{3} \mathrm{ha}^{-1}$ (2015) [7] (Fig. 5).

Table 4

The average of cumulative percentage change for round wood and energy wood supply development in 5-yr periods (2015-2030) between business as usual scenario (BAU) and intensive forest management scenario (INT). Year 2015 was compared to the previous year according to the statistics [7].

\begin{tabular}{lllll}
\hline & \multicolumn{2}{l}{ BAU (Absolute change) } & \multicolumn{2}{l}{ INT (Absolute change) } \\
\cline { 2 - 5 } & Roundwood & Energywood & Roundwood & Energywood \\
\hline 2015 & 5.9 & 0.5 & 6.3 & 0.5 \\
2020 & 5.9 & 0.5 & 6.5 & 0.7 \\
2025 & 5.9 & 0.5 & 6.7 & 0.9 \\
2030 & 6.0 & 0.6 & 7.0 & 1.1 \\
\hline
\end{tabular}


Table 5

The average of absolute change for round wood and energy wood supply development $\left(\mathrm{m}^{3} \mathrm{ha}^{-1}\right)$ in 5-yr period (2015-2030) between business as usual scenario (BAU) and intensive forest management scenario (INT). Year 2015 was the annual starting level.

\begin{tabular}{lllll}
\hline & \multicolumn{2}{c}{ BAU (\% change) } & \multicolumn{2}{c}{ INT (\% change) } \\
\cline { 2 - 5 } & Roundwood & Energywood & Roundwood & Energywood \\
\hline 2015 & 0.1 & 2.2 & 0.9 & 9.8 \\
2020 & 0.1 & 2.1 & 0.9 & 7.6 \\
2025 & 0.1 & 1.9 & 0.8 & 5.5 \\
2030 & 0.1 & 1.7 & 0.8 & 4.3 \\
\hline
\end{tabular}

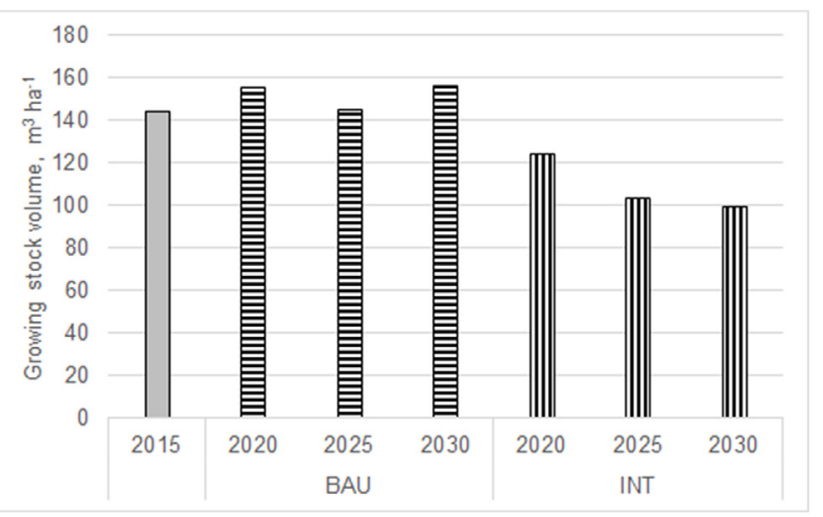

Fig. 5. The average of growing stock volume of simulated scenarios (in 5-yr periods 2020, 2025 \& 2030) compare to the current level (2015) [7] at South Savo region, $\mathrm{m}^{3} \mathrm{ha}^{-1}$.

\section{Discussion}

Despite a vast stock of literature on CGE models related to forestry [see, e.g. Ref. [34]] there are few (if any) CGE articles tackling the effects of intensive forest management on regional economies. This study is an attempt to fill that gap. Furthermore, our study integrated the latest forest inventory data (NFI11 [43]) into state-of-the-art stand projections (Motti stand simulator [see. e.g. Ref. [66]]) to create two alternative management options (business as usual, BAU and intensive management, INT). Then, the resulting cutting removals of the two options (BAU and INT) were further fed into a CGE model in order to evaluate the socio-economic impacts. We consider this framework to be a new approach that will contribute to the existing literature.

The results of the study indicated that the positive changes in the regional economy can be achieved with regional demand investments supported by more intensive forest biomass utilization. Favourable development of the regional economy of South Savo equates to an increase in private consumption, regional GDP and employment. The GDP would increase by $2.8 \%$, providing $€ 150$ million more to the regional economy by 2030 compared to baseline development (BAU). This percentage increase $(2.8 \%)$ in GDP falls into the range suggested by Ochuodho and Lantz [67] who assessed the welfare impacts (eg.GDP) of climate change in Canadian regions. The effect on employment would be 780 person-years larger by 2030 in the more intensive (INT) scenario than in BAU scenario. The study used CGE modelling for regional socioeconomic analysis, which describes not only the direct influences but also the multiplier impacts of additional investments and production. However, it is important to pay attention to the fact that the results are based on the investment and production estimates of the planned sawmill and the biorefinery. Changes to the estimates would be reflected in the results. Either way, the results represent well the possible regional economic impacts of the INT scenario.

In practice, the entire forest biomass potential should be analysed more precisely. There is a flip side behind the economic sustainability. More intensive cutting of old forests may decrease the ecological sustainability and carbon balance [68]. Especially, there is lot of uncertainty about the behaviour of soil carbon in boreal forests [69]. Complete sustainability analysis of forest biomass use should be linked with CGE modelling of regional economies. Few studies have linked environmental policy or carbon issues with CGE modelling [e.g. Refs. $[70,71]]$, not to mention the economic consequences for climate change in general [e.g. Ref. [72]]. On the other hand, in this study, the forest supply analysis was based on forest production land, which is not as sensitive for ecological aspects. In addition, if only carbon sequestration is increased in the forest without harvests, the source of renewable energy wood and materials would be lost [73]. Instead, the forest is the largest source of regional carbon balance at the regional level, which must be taken into consideration in follow-up studies.

Many uncertainties exist both in forest biomass supply and regional economy analysis. However, all the future scenarios selected were justified and potentially realizable in the regional economy. Political decision-makers and individual investors have a great deal of power to support regional forest biomass use for either industrial or energy investments. Our study showed that both industrial and energy sector investments are realistic according to the forest biomass supply potential and will have positive effect on regional economy. Investments can be encouraged not only for the advantage of individual companies but also as a common benefit for the regional economy.

More intensive forest management can produce forest biomass in a regionally more profitable manner, at least in the short-term, but it decreases the growing stock volume at the same time. Therefore, ecological and emission analysis, in turn, should be included in longer-term and more comprehensive analyses. The study showed a considerable forest biomass supply potential for both industrial round wood and energy wood. The forest biomass supply potential can be increased by using more intensive forest management with silvicultural practices and timing of harvesting operations. According to the study, the forest biomass supply potential could be increased on average by $1.7 \mathrm{Mm}^{3}$ (26\%) with a more intensive forest management regime (INT) when compared to the BAU scenario by 2030. This study increased information about the socio-economic impacts on intensive forest management at the regional level. Further analysis of ecological sustainability with emission analysis should be included in CGE modelling.

\section{Acknowledgements}

This work is a part of the project called "Impact of forest sector on regional economy of South Savo in Finland -Future vision on 2020 century" (12617), funded by The European Agricultural Fund for Rural Development. We want to thank for regional development funding opportunity.

\section{References}

[1] E. L Tompkins, W.N. Adger, Does adaptive management of natural resources enhance resilience to climate change? Ecol. Soc. 9 (2) (2004) 10 URL http://www. ecologyandsociety.org/vol9/iss2/art10/.

[2] M. Elbakidze, P. Angelstam, R. Axelsson, Sustainable forest management as an approach to regional development in the Russian Federation: state and trends in Kovdozersky Model Forest in the Barents region, Scand. J. For. Res. 22 (6) (2007) 568-581, https://doi.org/10.1080/02827580701804179.

[3] IPCC, 2014: summary for policymakers, in: O. Edenhofer, R. Pichs-Madruga, Y. Sokona, E. Farahani, S. Kadner, K. Seyboth, A. Adler, I. Baum, S. Brunner, P. Eickemeier, B. Kriemann, J. Savolainen, S. Schlomer, C. von Stechow, T. Zwickel, J.C. Minx (Eds.), Climate Change 2014, Mitigation of Climate Change. Contribution of Working Group III to the Fifth Assessment Report of the Intergovernmental Panel on Climate Change, Cambridge University Press, Cambridge, United Kingdom and New York, NY, USA, 2014.

[4] P. Peura, A. Haapanen, K. Reini, H. Törmä, Regional impacts of sustainable energy in Western Finland, J. Clean. Prod. (2018), https://doi.org/10.1016/j.jclepro.2018. 03.194.

[5] M. Brinkman, M. Cunha, S. Heijnen, B. Wicke, J. Guilhoto, A. Walter, A. Faaij, F. van der Hilst, Interregional assessment of socio-economic effects of sugarcane 
ethanol production in Brazil, Renew. Sustain. Energy Rev. 88 (2018) 347-362 ISSN 1364-0321 https://doi.org/10.1016/j.rser.2018.02.014.

[6] R. Duarte, J. Sánchez-Chóliz, C. Sarasa, Consumer-side actions in a low-carbon economy: a dynamic CGE analysis for Spain, Energy Pol. 118 (2018) 199-210 ISSN 0301-4215 https://doi.org/10.1016/j.enpol.2018.03.065.

[7] Natural Resources Institute Finland, (2016) http://stat.luke.fi/en/metsa.

[8] Ministry of agriculture and forestry, Kansallinen Metsästrategia 2025 Valtioneuvoston Periaatepäätös 12 vol. 2, (2015).

[9] National Energy and Climate Strategy, MEE Publications, 2013, p. 55 Energy and the climate 8 https://tem.fi/documents/1410877/2769658/National + Energy + and + Climate + Strategy + 2013/630dc2c6-4a23-4f2e-b304-3cd69daf8265.

[10] E. Ylitalo, Puun Energiakäyttö 2015. [The Use of wood for Energy 2015], (2016) http://stat.luke.fi/puun-energiakaytto.

[11] R. Björheden, Integrated production of timber and energy: a comprehensive view, N. Z. J. For. Sci. 30 (1/2) (2000) 67-78.

[12] J. Heikkilä, M. Sirén, A. Ahtikoski, J. Hynynen, T. Sauvula, M. Lehtonen, Energy wood thinning as a part of the stand management of Scots pine and Norway spruce, Silva Fenn. 43 (1) (2009) 129-146 https://doi.org/10.14214/sf.220.

[13] K. Karttunen, J. Laitila, Forest management regime options for integrated smalldiameter wood harvesting and supply chain from young Scots pine (Pinus sylvestris L.) stands, Int. J. For. Eng. (2015), https://doi.org/10.1080/14942119.2015. 1083749.

[14] K. Karttunen, J. Laitila, T. Ranta, First-thinning harvesting alternatives for industrial or energy purposes based on regional Scots pine stand simulations in Finland, Silva Fenn. 50 (2) (2016) id1521 https://doi.org/10.14214/sf.1521.

[15] T. Ranta, Logging residues from regeneration fellings for biofuel production-a GISbased availability analysis in Finland, Biomass Bioenergy 28 (2005) 171-182 https://doi.org/10.1016/j.biombioe.2004.08.010.

[16] T. Ranta, O.-J. Korpinen, E. Jappinen, K. Karttunen, Forest biomass availability analysis and large-scale supply options, Open J. For. 2 (2012) 33 https://doi.org/ 10.4236/ojf.2012.21005.

[17] P. Anttila, M. Nivala, J. Laitila, K.T. Korhonen, Metsähakkeen alueellinen korjuupotentiaali ja käyttö, Metlan Työraportteja/Working Papers of the Finnish Forest Research Institute, 2013 267. 24 s, ISBN 978-951-40-2420-7 (PDF). [in Finnish] http://www.metla.fi/julkaisut/workingpapers/2013/mwp267.htm.

[18] M. Nivala, P. Anttila, J. Laitila, O. Salminen, M. Flyktman, A GIS-based methodology to estimate the regional balance of potential and demand of forest chips, J. Geogr. Inf. Syst. 8 (2016) 633-662 https://doi.org/10.4236/jgis.2016.85052.

[19] T. Yoshioka, R. Sakurai, K. Aruga, H. Sakai, H. Kobayashi, K. Inoue, A GIS based analysis on the relationship between the annual available amount and the procurement cost of forest biomass in a mountainous region in Japan, Biomass Bioenergy 35 (2011) 4530-4537 https://doi.org/10.1016/j.biombioe.2011.03.029.

[20] C.E. Noon, M.J. Daly, Strategic benefits of biomass and wasteful fuels GIS based biomass resource assessment with BRAVO, Biomass Bioenergy 10 (1996) 101-109 https://doi.org/10.1016/0961-9534(95)00065-8.

[21] S. Sanchez-Garcia, E. Canga, E. Tolosana, J. Majada, A spatial analysis of woodfuel based on WISDOM GIS methodology: multiscale approach in northern Spain, Appl. Energy 144 (2015) 193-203 https://doi.org/10.1016/j.apenergy.2015.01.099.

[22] S. Bouchard, M. Landry, Y. Gagnon, Methodology for the large scale assessment of the technical power potential of forest biomass: application to the province of new brunswick, Canada, Biomass Bioenergy 54 (2013) 1-17 https://doi.org/10.1016/j. biombioe.2013.03.014.

[23] P.K. Rorstad, E. Tromborg, E. Bergseng, B. Solberg, Combining GIS and forest modelling in estimating regional supply of harvest residues in Norway, Silva Fenn. 44 (2010) 435-451 https://doi.org/10.14214/sf.141.

[24] P. Hakkila, Wood Energy Technology Programme 1999-2003, Final Report. Technology.Programme Report 5 (2004).

[25] A.-K. Rämö, E. Järvinen, T. Latvala, R. Toivonen, H. Silvennoinen, Interest in energy wood and energy crop production among Finnish non-industrial private forest owners, Biomass Bioenergy 33 (2009) 1251-1257, https://doi.org/10.1016/j. biombioe.2009.05.013.

[26] S. Mynttinen, K. Karttunen, T. Ranta, Non-industrial private forest owners' willingness to supply forest-based energy wood in the South Savo region in Finland, Scand. J. For. Res. 29 (1) (2013) 41-50 https://doi.org/10.1080/02827581.2013 856935.

[27] T. Ranta, A. Karhunen, M. Laihanen, Factors behind the development of forest chips use and pricing in Finland, Biomass Bioenergy 98 (2017) 243-251 https://doi.org/ 10.1016/j.biombioe.2017.02.004.

[28] J.S. Bandara, Computable general equilibrium models for development policy analysis in LDCs, J. Econ. Surv. 5 (1) (1991) 3-69.

[29] O. Banerjee, J. Alavalapati, A computable general equilibrium analysis of forest concessions in Brazil, For. Pol. Econ. 11 (2009) 244-252.

[30] P.B. Dixon, R.B. Koopman, M.T. Rimmer, The monash style of computable general equilibrium modeling: a framework for practical policy analysis, in: P.B. Dixon, D.W. Jorgenson (Eds.), Handbook of Computable General Equilibrium Modeling, 1A Elsevier/North Holland, 2013.

[31] T.F. Rutherford, H. Törmä, Efficiency of fiscal measures in preventing out-migration from North Finland, Reg. Stud. 44 (4) (2010) 465-475.

[32] L.J. Corbett, P. Whitney, V.A. Lantz, T.O. Ochuodho, The economic impact of the mountain pine beetle infestation in British Columbia: provincial estimates from a CGE analysis, Forestry 89 (2016) 100-105.

[33] T.O. Ochuodho, V.A. Lantz, Economic impacts of climate change in the forest sector: a comparison of single-region and multiregional CGE modeling frameworks, Can. J. For. Res. 44 (2014) 449-464.

[34] K.A. Babatunde, R.A. Begum, F.F. Sid, Application of computable general equilibrium (CGE) to climate change mitigation policy: a systematic review, Renew.
Sustain. Energy Rev. 78 (2017) 61-71.

[35] L.C. Stenberg, M. Siriwardana, The appropriateness of CGE modeling in analyzing the problem of deforestation, Manag. Environ. Qual. Int. J. 16 (5) (2005) 407-420.

[36] M. Wiebelt, Protecting Brazil's Tropical forest: a CGE Analysis of Macroeconomic, Sectoral and Regional Policies, Kiel Institute of World Economics, 1994, pp. 1-30 Kiel Working Paper No.638.

[37] J.R. R Alavalapati, M.B. Percy, M.K. Luckert, A computable general equilibrium analysis of a stumpage price increase policy in British Columbia, J. For. Econ. 3 (2) (1997) 143-169.

[38] J. Gan, Forest certification costs and global forest product markets and trade: a general equilibrium analysis, Can. J. For. Res. 35 (7) (2005) 1731-1743.

[39] G.G. Das, J.R.R. Alavalapati, D.R. Carter, M.E. Tsigas, Regional impacts of environmental regulations and technical change in the US forestry sector: a multiregional CGE analysis, For. Pol. Econ. 7 (2005) 25-38.

[40] L.C. Stenberg, M. Siriwardana, Forest conservation in the Philippines: an economic assessment of selected policy responses using a computable equilibrium model, For. Pol. Econ. 9 (6) (2007) 671-693.

[41] J.L. Monge, H.L. Bryant, J. Gan, J.W. Richardson, Land use and general equilibrium implications of a forest-based carbon sequestration policy in the United States, Ecol. Econ. 127 (2016) 102-120.

[42] Metsäkeskus, Etelä-savon Metsäohjelma 2016-2020, (2006) ISBN 978-952-283039-5 https://www.metsakeskus.fi/sites/default/files/smk-alueellinenmetsaohjelma-etela-savo.pdf.

[43] K.T. Korhonen, A. Thalainen, A. Ahola, J. Heikkinen, H. Henttonen, J.-P. Hotanen, S. Nevalainen, J. Pitkänen, M. Strandström, H. Viiri, Suomen Metsät 2009-2013 Ja Niiden Kehitys 1921-2013. Luonnonvarakeskus, Luonnonvara- Ja Biotalouden Tutkimus 59 (2017), p. 86.

[44] H. Törmä, S. Kujala, J. Kinnunen, The employment and population impacts of the boom and bust of Talvivaara mine in the context of severe environmental accidents - a CGE evaluation, Resour. Pol. 26 (2015) 127-138.

[45] A. Matilainen, S. Keskinarkaus, H. Törmä, The economic significance of hunting tourism in east Lapland, Finland, Hum. Dimens. Wildl. 21 (3) (2016), https://doi. org/10.1080/10871209.2016.1129652.

[46] G. Wittwer (Ed.), Economic Modeling of Water: the Australian CGE Experience, Springer, 2012.

[47] M. Horridge, G. Wittwer, Bringing regional detail to a CGE model using census data, Spatial Econ. Anal. 5 (2) (2010) 229-255 (Routledge).

[48] P. Adams, J. Dixon, J. Giesecke, M. Horridge, MMRF: Monash Multi-regional Forecasting Model: a Dynamic Multi-regional Model of the Australian Economy, Centre of Policy Studies, Monash University, 2010 General Paper No. G-223 December.

[49] Statistics Finland, Input-output (e-publication), Statistics Finland, Helsinki, 2016 ISSN = 1799-201X http://www.stat.fi/til/pt/tau_en.html.

[50] Statistics Finland, Regional Account (e-publication), Statistics Finland, Helsinki, 2017http://www.stat.fi/til/altp/index_en.html.

[51] Statistics Finland, Population projection (e-publication), Statistics Finland, Helsinki, 2015 ISSN = 1798-5153 http://www.stat.fi/til/vaenn/2015/vaenn_2015 2015-10-30 tie 001 en.html.

[52] Natural Resources Institute Finland, Stumpage Earnings, (2016) http://stat.luke.fi/ en/stumpage-earnings.

[53] Ministry of Finance, Economic Forecasts, (2016) Available: http://vm.fi/en/ economic-forecasts.

[54] Economic Policy Council, Economic Policy Council Report 2016, Työvoiman Tarve Suomen Taloudessa Vuosina 2015-2030 VATT Institute for Economic Research, (2017) Helsinki https://www.talouspolitiikanarviointineuvosto.fi/wordpress/wpcontent/uploads/2017/01/economic-policy-council-report-2016.pdf.

[55] J. Ahokas, J. Honkatukia, M. Lehmus, J. Niemi, A. Simola, S. Tamminen, VATT Tutkimukset 181, VATT Institute for Economic Reasearch, Helsinki, 2015http:// vatt.fi/documents/2956369/3012201/t181.pdf/b1ca0152-dd51-4254-85f66f391738947d.

[56] Victoria University, GEMPACK General Equilibrium Modelling Software, (2018) https://www.copsmodels.com/gempack.htm.

[57] H. Salminen, M. Lehtonen, J. Hynynen, Reusing legacy FORTRAN in the MOTTI growth and yield simulator, Comput. Electron. Agric. 49 (1) (2005) 103-113.

[58] J. Hynynen, H. Salminen, A. Ahtikoski, S. Huuskonen, R. Ojansuu, J. Siipilehto, M. Lehtonen, A. Rummukainen, S. Kojola, K. Eerikäinen, Scenario analysis for the biomass supply potential and the future development of Finnish forest resources, Metla Working papers 302 (2014) 116.

[59] J. Hynynen, H. Salminen, A. Ahtikoski, S. Huuskonen, R. Ojansuu, J. Siipilehto, M. Lehtonen, K. Eerikäinen, Long-term impacts of forest management on biomass supply and forest resource development: a scenario analysis for Finland, Eur. J. For. Res. 134 (2015) 415-431 https://doi.org/10.1007/s10342-014-0860-0.

[60] J. Hynynen, R. Ojansuu, H. Hökkä, J. Siipilehto, H. Salminen, P. Haapala, Models for Predicting Stand Development in MELA System, Metsäntutkimuslaitos, 2002.

[61] S. Huuskonen, A. Ahtikoski, Ensiharvennuksen ajoituksen ja voimakkuuden vaikutus kuivahkon kankaan männiköiden tuotokseen ja tuottoon, Metsätieteen aikakauskirja 2 (2005) 99-115 http://www.metla.fi/aikakauskirja/full/ff05/ff052099. pdf.

[62] S. Huuskonen, Nuorten männiköiden kehitys - taimikonhoito ja ensiharvennus, Silva Fennica (62) (2008) 1844https://doi.org/10.14214/df.62.

[63] H. Mäkinen, J. Hynynen, A. Isomäki, Intensive management of Scots pine stands in southern Finland: first empirical results and simulated further development, For. Ecol. Manag. 215 (2005) 37-50 https://doi.org/10.1016/j.foreco.2005.03.069.

[64] J. Hynynen, A. Ahtikoski, J. Siitonen, R. Sievänen, J. Liski, Applying the MOTTI simulator to analyse the effects of alternative management schedules on timber and non-timber production, For. Ecol. Manage. 207 (2005) 5-18 https://doi.org/10. 
1016/j.foreco.2004.10.015.

[65] S. Rantala (Ed.), Finnish Forestry Practice and Management, Metsäkustannus, Helsinki, 2011.

[66] A. Juutinen, A. Ahtikoski, M. Lehtonen, R. Mäkipää, M. Ollikainen, The impact of a short-term carbon payment scheme on forest management, For. Pol. Econ. 90 (2018) 115-127.

[67] T.O. Ochuodho, V.A. Lantz, Economic impacts of climate change on agricultural crops in Canada by 2051: a global multi-regional CGE model analysis, Environ. Econ. 6 (2015) 113-125.

[68] S. Luyssaert, E.-D. Schulze, A. Börner, A. Knohl, D. Hessenmöller, B.E. Law, P. Ciais, J. Grace, Old-growth forests as global carbon sinks, Nature 455 (2008) 213-215.

[69] J.A. Corey, I. Bradshaw, Warkentin, Global estimates of boreal forest carbon stocks and flux, Global Planet. Change 128 (2015) 24-30 ISSN 0921-8181 https://doi. org/10.1016/j.gloplacha.2015.02.004.

[70] L. Bergman, General equilibrium effects of environmental policy: a CGE-modeling approach, Environ. Resour. Econ. 1 (1) (1991) 43-61.

[71] R.J. Plevin, J. Beckman, A.A. Golub, J. Witcover, M. O'Hare, Carbon accounting and economic model uncertainty of emissions from biofuels-induced land use change, Environ. Sci. Technol. 49 (5) (2015) 2656-2664.

[72] N. Stern, Stern Review Report on the Economics of Climate Change, Technical report (2006).

[73] K. Koponen, L. Sokka, O. Salminen, R. Sievänen, K. Pingoud, H. Ilvesniemi, J. Routa, T. Ikonen, T. Koljonen, E. Alakangas, A. Asikainen, K. Sipilä, Sustainability of forest energy in northern Europe, VTT Technology 237 (2015) 94 http://www. vtt.fi/inf/pdf/technology/2015/T237.pdf. 